\title{
Article
}

Mycosphere

\section{Lignicolous freshwater fungi from China I : Aquadictyospora lignicola gen. et sp. nov. and new record of Pseudodictyosporium wauense from northwestern Yunnan Province}

\author{
Li WL ${ }^{1,2^{*}}$, Luo ZL ${ }^{1,3^{*}}$, Liu JK ${ }^{4,5}$, Bhat $\mathrm{DJ}^{6}$, Bao DF ${ }^{1}$, Su HY ${ }^{1 * 7}$, Hyde $\mathrm{KD}^{3}$ \\ ${ }^{I}$ College of Agricultural \& Biological Sciences, Dali University, Dali 671003, Yunnan, P.R. China \\ ${ }^{2}$ College of Basic Medicine, Dali University, Dali 671003, Yunnan, P.R. China \\ ${ }^{3}$ Center of Excellence in Fungal Research, Mae Fah Luang University, Chiang Rai 57100, Thailand \\ ${ }^{4}$ Guizhou Institute of Biotechnology, Guizhou Academy of Agricultural Sciences, Guiyang 550006, P.R. China. \\ ${ }^{5}$ Guizhou Key Laboratory of Agricultural Biotechnology, Guizhou Academy of Agricultural Sciences, Guiyang 550006, \\ P.R. China \\ ${ }^{6}$ Formerly at Department of Botany, Goa University, Goa, 403206, India \\ ${ }^{7}$ Yunnan Provincial Key Laboratory of Entomological Biopharmaceutical R\&D, Dali 671003, Yunnan, P.R. China \\ ${ }^{\dagger}$ These authors have equally contributed to this paper.
}

Li WL, Luo ZL, Liu JK, Bhat DJ, Bao DF, Su HY, Hyde KD 2017 - Lignicolous freshwater fungi from China I : Aquadictyospora lignicola gen. et sp. nov. and new record of Pseudodictyosporium wauense from northwestern Yunnan Province. Mycosphere 8(10), 1587-1597, Doi 10.5943/mycosphere/8/10/1

\begin{abstract}
This is the first in a series of papers on lignicolous freshwater fungi from China. In this paper, eight fresh collections of taxa of Dictyosporiaceae from submerged wood in freshwater are characterized based on morphological characters and phylogenetic analyses of combined ITS, LSU and TEF $1 \alpha$ sequence data. A new monotypic genus Aquadictyospora, with A. lignicola as the type species is introduced based on its distinct morphology and evidences from molecular phylogeny. In addition, detailed description and illustration of Pseudodictyosporium wauense from the fresh collection are provided and it is a new record for China.
\end{abstract}

Key words - Asexual fungi - Dictyosporiaceae - Phylogeny - Taxonomy

\section{Introduction}

Lignicolous freshwater fungi grow on submerged woody debris in freshwater streams, ponds, lakes and tree hollows (Goh \& Hyde 1996, Wong et al. 1998). These taxa play an important role in the decomposition of submerged wood in aquatic habitats by breaking down lignocelluloses and releasing nutrients and are important in ecosystem functioning (Yuen et al. 1998, Bucher et al. 2004, Hyde et al. 2016). The lignicolous freshwater fungi are a taxonomically highly diverse group and mostly encountered in two major classes, Dothideomycetes and Sordariomycetes of the Ascomycota (Hyde et al. 2013, Wijayawardene et al. 2014, Maharachchikumbura et al. 2015, 2016, Liu et al. 2017).

Studies of freshwater fungi in China were first documented in 1988. He (1988) reported Vibrissea truncorum (Alb. \& Schwein.) Fr. on submerged wood in Guizhou Province. This was probably the first record of lignicolous freshwater fungi in China. About ten years later, 
mycologists started to investigate the lignicolous freshwater fungi in Hong Kong and reported many new taxa (Tsui et al. 1997, 2000, 2001a, b, 2003, Goh et al. 1998, Hyde \& Goh 1998, Ranghoo \& Hyde 1998, Goh \& Hyde 1999, Ho et al. 1999). In mainland China, investigations of lignicolous freshwater fungi mostly focused in the south to southwestern regions (Inderbitzin 2000, Jeewon et al. 2003, Cai et al. 2005, Hu et al. 2013). Cai et al. (2002) investigated the fungal diversity in Fuxian Lake in Yunnan Province and reported 64 higher fungi, with a new ascomycete Pseudohalonectria fuxianii L. Cai, K.M. Tsui, K.Q. Zhang \& K.D. Hyde, while Luo et al. (2004) reported fungi from Dianchi Lake. Many new taxa have since been described including several new genera (Inderbitzin 2000, Jeewon et al. 2003, Cai et al. 2005, Cai \& Hyde 2007, Wongsawas et al. 2009a, b , Hu et al. 2012, Liu et al. 2015, Su et al. 2015, 2016a, b, Luo et al. 2016, 2017, Wang et al. 2016, Zhu et al. 2016). Hu et al. (2013) also published a review paper of aquatic fungi in China.

Pleosporales is the largest order in the Dothideomycetes, and in recent years, various families and genera in the Pleosporales have undergone considerable revisions and their taxonomy and phylogeny have been reassessed (Goh et al. 1999, Tanaka et al. 2009, 2015, Zhang et al. 2012, Hyde et al. 2013). Dictyosporiaceae was introduced to accommodate a holomorphic group of Dothideomycetes that are saprobes on decaying wood and plants debris in terrestrial and freshwater habitats (Liu et al. 2015, Boonmee et al. 2016). The asexual morphs of Dictyosporiaceae are characterized by brown, multi-septate, cheirosporous conidia, produced from holoblastic conidiogenous cells, on micronematous conidiophores (Boonmee et al. 2016).

We are carrying out a survey of the diversity of lignicolous freshwater fungi along a northsouth gradient in the Asian region (Hyde et al. 2016). To investigate the diversity of the freshwater fungi in China, we selected southwestern China (Yunnan Province), where there are several important rivers selected to study. This area is believed to have unique and diverse ecology and diversity, which have been shown by studies on plants and animals, as well as fungi (Yang et al. 2004). This is the first in a series of papers on these fungi in southwestern China, and a new genus Aquadictyospora which assign in Dictyosporiaceae (Pleosporales, Dothideomycetes) was established based on the morphological and phylogenetic analyses. In addition, a fresh collection was identified as Pseudodictyosporium wauense Matsush., the detailed description and illustration are provided, and it is the new record for China.

\section{Materials \& Methods}

Submerged woody substrates were collected from a stream in Cangshan Mountain, Yunnan Province, China, and taken back to the laboratory in Zip-lock plastic bags. The samples were incubated in sterile humid plastic boxes for $1-3$ weeks at $25-32^{\circ} \mathrm{C}$, and processed following the methods described in Taylor \& Hyde (2003). Specimens were studied under a Motic SMZ 168 Series stereoscope and photographed by OLYMPUS BX51 microscope imaging system. Measurements of the fungal structures were taken with Image-Pro-Express software.

The pure cultures were attempted by single spore isolation followed Chomnunti et al. (2014). The cultures are deposited in Mae Fah Luang University Culture Collection (MFLUCC) and Dali University Culture Collection (DLUCC). Herbarium specimens are deposited at the herbarium of Mae Fah Luang University (MFLU) and Dali University (DLU). Facesoffungi and Index Fungorum numbers were obtained as in Jayasiri et al. (2015) and Index Fungorum (2017).

\section{DNA extraction, PCR amplification and sequencing}

Total genomic DNA was extracted from fresh mycelia grown on PDA at $25-32^{\circ} \mathrm{C}$ for 30 to 45 d. The EZ geneTM Fungal gDNA kit (GD2416) was used to extract DNA according to the manufacturer's instructions. The primer pairs ITS5/ITS4 (White et al 1990), LROR/LR7 (Vilgalys \& Hester 1990) and EF1-983F/EF1-2218R (Carbone \& Kohn 1999) were used to amplify the gene regions of ITS, LSU and TEF1 $\alpha$ respectively. The PCR thermal cycle program for ITS and LSU amplification was as follows: initial denaturation of $94{ }^{\circ} \mathrm{C}$ for 3 mins, followed by 40 cycles of denaturation at $95{ }^{\circ} \mathrm{C}$ for 30 seconds, annealing at $55^{\circ} \mathrm{C}$ for 50 seconds, elongation at $72{ }^{\circ} \mathrm{C}$ for 1 min. Regions of TEF $1 \alpha$ was amplified with initial denaturation of $95^{\circ} \mathrm{C}$ for $5 \mathrm{~min}$, followed by 40 
cycles of denaturation at $95{ }^{\circ} \mathrm{C}$ for $1 \mathrm{~min}$, annealing at $54{ }^{\circ} \mathrm{C}$ for 90 seconds, elongation at $72{ }^{\circ} \mathrm{C}$ for 90 seconds, and the final extension at $72{ }^{\circ} \mathrm{C}$ for $10 \mathrm{mins}$ included for each condition of amplification. PCR products were purified using minicolumns, purification resin and buffer according to the manufacturer's protocols (Amershamproduct code: 27-9602-01). The sequencing works were carried by Beijing Tsingke Biological Engineering Technology and Services Co., Ltd (Beijing, P.R. China).

\section{Phylogenetic analysis}

Sequence data for relevant strains were downloaded from GenBank following recent publications (Boonmee et al. 2016, Wang et al. 2016). Consensus sequences were assembled with Sequencher 4.9 for Windows (Gene Codes Corp., Ann Arbor, Michigan) and aligned using MAFFT v.7.110 online program (http://mafft.cbrc.jp/alignment/server/) (Katoh \& Standley 2013) and manually adjusted via BioEdit v7.2.3 (Hall 1999). A maximum likelihood (ML) analysis was performed using RAxMLGUI v. 1.3 (Silvestro \& Michalak 2011). The optimal ML tree search was conducted with 1000 separate runs, using the default algorithm of the program from a random starting tree for each run. The final tree was selected among suboptimal trees from each run by comparing likelihood scores under the GTR+GAMMA substitution model.

Bayesian analyses were performed by using PAUP v.4.0b10 (Swofford 2002) and MrBayes v3.2.2 (Ronquist et al. 2012). The model of evolution was estimated by using MrModeltest 2.2 (Nylander 2004). Posterior probabilities (Rannala \& Yang 1996) were performed by Markov Chain Monte Carlo Sampling (BMCMC) in MrBayes v. 3.0b4. Six simultaneous Markov Chains were run for 1,000,000 generations and trees were sampled every 100th generation (resulting in 10000 trees). The first 2000 trees representing the burn-in phase of the analyses were discarded and the remaining 8000 (post burning) trees used for calculating posterior probabilities (PP) in the majority rule consensus tree.

All new sequence data generated in this study are deposited in GenBank (Table 1) and alignments are submitted to TreeBASE (www.treebase.org, submission number 21532). Resulted trees were viewed in Treeview (Page 1996). The terminals of the tree (Fig. 1) are labeled with species and the isolates/culture collection codes as provided in GenBank.

Table 1 Isolates and sequences used in this study (newly generated sequences are indicated in bold, ex-type strains are indicated in * after collection number).

\begin{tabular}{|c|c|c|c|c|}
\hline \multirow{2}{*}{ Species } & \multirow{2}{*}{$\begin{array}{c}\text { Collection/Isolate } \\
\text { number }\end{array}$} & \multicolumn{3}{|c|}{ GenBank accession number } \\
\hline & & ITS & LSU & TEF $1 \alpha$ \\
\hline Aquaticheirospora lignicola & RK 2006a* & AY864770 & AY736378 & - \\
\hline Aquadictyospora lignicola & MFLUCC 17-1318* & MF948621 & MF948629 & MF953164 \\
\hline Cheirosporium triseriale & HMAS $180703^{*}$ & EU413953 & EU413954 & - \\
\hline Dendryphiella fasciculata & MFLUCC 17-1074* & MF399213 & MF399214 & - \\
\hline Dendryphiella paravinosa & CBS $141286^{*}$ & KX228258 & KX228309 & - \\
\hline Dendryphiella eucalyptorum & CBS 137987 & KJ869139 & KJ869196 & - \\
\hline Dictyocheirospora aquatica & KUMCC $15-0305^{*}$ & KY320508 & KY320513 & - \\
\hline Dictyocheirospora bannica & KH 332 & LC014543 & AB807513 & AB808489 \\
\hline Dictyocheirospora garethjonesii & MFLUCC 16-0909* & KY320509 & KY320514 & - \\
\hline Dictyocheirospora garethjonesii & KUMCC 15-0396 & KY320510 & KY320515 & - \\
\hline Dictyocheirospora garethjonesii & DLUCC 0848 & MF948623 & MF948631 & MF953166 \\
\hline Dictyocheirospora rotunda & MFLUCC 14-0293* & KU179099 & KU179100 & - \\
\hline Dictyocheirospora rotunda & DLUCC 0856 & MF948624 & MF948632 & MF953167 \\
\hline Dictyocheirospora rotunda & MFLUCC 17-1687 & MF948625 & MF948633 & MF953168 \\
\hline Dictyocheirospora rotunda & DLUCC 0747 & MF948626 & MF948634 & MF953169 \\
\hline Dictyocheirospora rotunda & DLUCC 0804 & MF948627 & MF948635 & MF953170 \\
\hline Dictyocheirospora pseudomusae & KH 412 & LC014549 & $\mathrm{AB} 807516$ & AB808492 \\
\hline Dictyocheirospora pseudomusae & yone $234^{*}$ & LC014550 & $\mathrm{AB} 807520$ & AB808496 \\
\hline Dictyocheirospora vinaya & MFLUCC 14-0294* & KU179102 & KU179103 & - \\
\hline Dictyosporium aquaticum & MF1318* & KM610236 & - & - \\
\hline
\end{tabular}


Table 1 Continued.

\begin{tabular}{|c|c|c|c|c|}
\hline \multirow{2}{*}{ Species } & \multirow{2}{*}{$\begin{array}{c}\text { Collection/Isolate } \\
\text { number }\end{array}$} & \multicolumn{3}{|c|}{ GenBank accession number } \\
\hline & & ITS & LSU & TEF $1 \alpha$ \\
\hline Dictyosporium elegans & NBRC $32502^{*}$ & DQ018087 & DQ018100 & - \\
\hline Dictyosporium hughesii & KT 1847 & LC014548 & $\mathrm{AB} 807517$ & AB808493 \\
\hline Dictyosporium meiosporum & MFLUCC 10-0131* & KP710944 & KP710945 & - \\
\hline Dictyosporium tetrasporum & KT 2865 & LC014551 & AB807519 & AB808495 \\
\hline Dictyosporium thailandicum & MFLUCC 13-0773* & KP716706 & KP716707 & - \\
\hline Digitodesmium bambusicola & CBS $110279^{*}$ & DQ018091 & DQ018103 & - \\
\hline Gregarithecium curvisporum & KT $922^{*}$ & AB809644 & AB807547 & - \\
\hline Jalapriya inflata & NTOU 3855 & JQ267362 & JQ267363 & - \\
\hline Jalapriya pulchra & MFLUCC $15-0348$ & KU179108 & KU179109 & - \\
\hline Jalapriya pulchra & MFLUCC 17-1683 & MF948628 & MF948636 & MF953171 \\
\hline Jalapriya toruloides & CBS 209.65 & DQ018093 & DQ018104 & - \\
\hline Periconia igniaria & CBS 379.86 & LC014585 & AB807566 & AB808542 \\
\hline Periconia igniaria & CBS 845.96 & LC014586 & AB807567 & AB808543 \\
\hline $\begin{array}{l}\text { Pseudocoleophoma } \\
\text { calamagrostidis }\end{array}$ & KT $3284^{*}$ & LC014592 & LC014609 & LC014614 \\
\hline Pseudocoleophoma polygonicola & KT $731^{*}$ & AB809634 & AB807546 & AB808522 \\
\hline Pseudocoleophoma typhicola & MFLUCC $16-0123^{*}$ & KX576655 & KX576656 & - \\
\hline Pseudodictyosporium elegans & CBS $688.93^{*}$ & DQ018099 & DQ018106 & - \\
\hline Pseudodictyosporium indicum & CBS 471.95 & DQ018097 & - & - \\
\hline Pseudodictyosporium thailandica & MFLUCC 16-0029* & KX259520 & KX259522 & KX259526 \\
\hline Pseudodictyosporium wauense & NBRC 30078 & DQ018098 & DQ018105 & - \\
\hline Pseudodictyosporium wauense & KRP88-6 & HМ036613 & - & - \\
\hline Pseudodictyosporium wauense & DLUCC 0801 & MF948622 & MF948630 & MF953165 \\
\hline Vikalpa australiensis & HKUCC $8797^{*}$ & DQ018092 & - & - \\
\hline
\end{tabular}

\section{Results}

\section{Phylogenetic analyses}

The combined ITS, LSU and TEF1 $\alpha$ dataset consisted 43 sequences representing all genera of the Dictyosporiaceae and Periconia igniaria (CBS 379.86, CBS 845.96) was selected as out group. The alignment comprised 2674 characters, of which 2000 were constant, 485 parsimonyinformative and 189 parsimony-uninformative. The best scoring RaxML tree is shown here (Figure 1) (value of likelihood: -12295.132955). The robust clade containing 12 genera (100 ML/1.00 Bayesian) has identical topologies in the multi-gene analyses (Fig. 1). In particular, the newly collected Dictyocheirospora rotunda, D. garethjonesii and Jalapriya pulchra isolates cluster with their type strain respectively with highly supported value (100 ML/1.00 Bayesian). The new isolate of Pseudodictyosporium wauense also cluster with its identified strains from previous studies. The isolate of Aquadictyospora formed a distinct clade among the genera of Dictyosporiaceae.

\section{Taxonomy}

Aquadictyospora Z.L. Luo, K.D. Hyde \& H.Y. Su, gen. nov.

Index Fungorum number: IF553861; Facesoffungi number: FoF03767

Etymology - referring to the aquatic habitats and shape of the conidia of the fungus.

Saprobic on submerged decaying wood. Sexual morph: Undetermined. Asexual morph: Conidiomata on natural substratum sporodochia, superficial, compact, scattered, circular or subglobose, dark brown to black, velvety. Mycelium immersed, consisted of septate, branched, smooth, thin-walled, hyaline hyphae. Conidiophores micronematous, reduced to conidiogenous cells, pale brown, smooth. Conidiogenous cells monoblastic. Conidia appearing broadly rounded, composed of 4-6 compactly arranged rows of uniformly medium brown cells in upper half, with a basal, subglobose, hyaline cell, not complanate. Conidial appendages absent.

Type species - Aquadictyospora lignicola Z.L. Luo, W.L. Li, K.D. Hyde \& H.Y. Su Aquadictyospora lignicola Z.L. Luo, W.L. Li, K.D. Hyde \& H.Y. Su, sp. nov. 


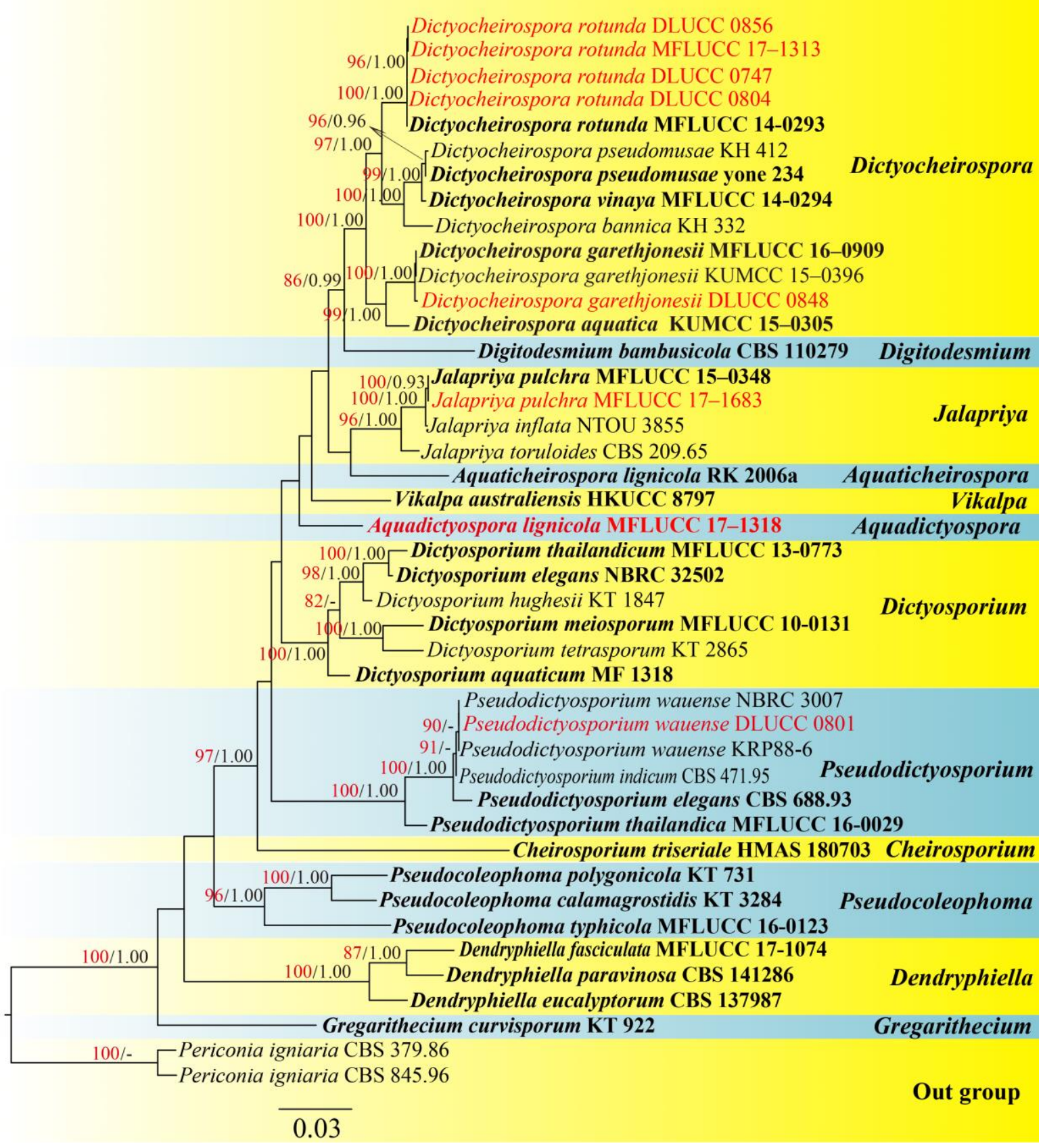

Figure 1 Phylogram generated from maximum likelihood analysis (RAxML) based on combined ITS, LSU and TEF $1 \alpha$ sequence data of Dictyosporiaceae. Bootstrap support values for maximum likelihood (red) and Bayesian posterior probabilities (black) greater than $75 \%$ and 0.95 are given above the nodes. The tree is rooted to Periconia igniaria (CBS 379.86, CBS 845.96). Newly generated sequences are indicated in red and ex-type strains are in bold.

Index Fungorum number: IF553862; Facesoffungi number: FoF03768, Fig. 2

Etymology - The name lignicola is derived from the words 'lignum', meaning wood and cola, meaning habitat, referring to the habitat in which this fungus was found.

Holotype - MFLU 17-1422

Saprobic on submerged decayed wood in aquatic habitats. Sexual morph: Undetermined. Asexual morph: Hyphomycetous. Conidiomata on natural substratum sporodochia, $200 \mu \mathrm{m}$ to 1 mm diam., superficial, compact, scattered, circular or subglobose, dark brown to black, velvety. Mycelium immersed, consisted of septate, branched, smooth, thin-walled, hyaline, 2-4 $\mu \mathrm{m}$ wide hyphae. Conidiophores micronematous, reduced, pale brown, smooth. Conidiogenous cells 

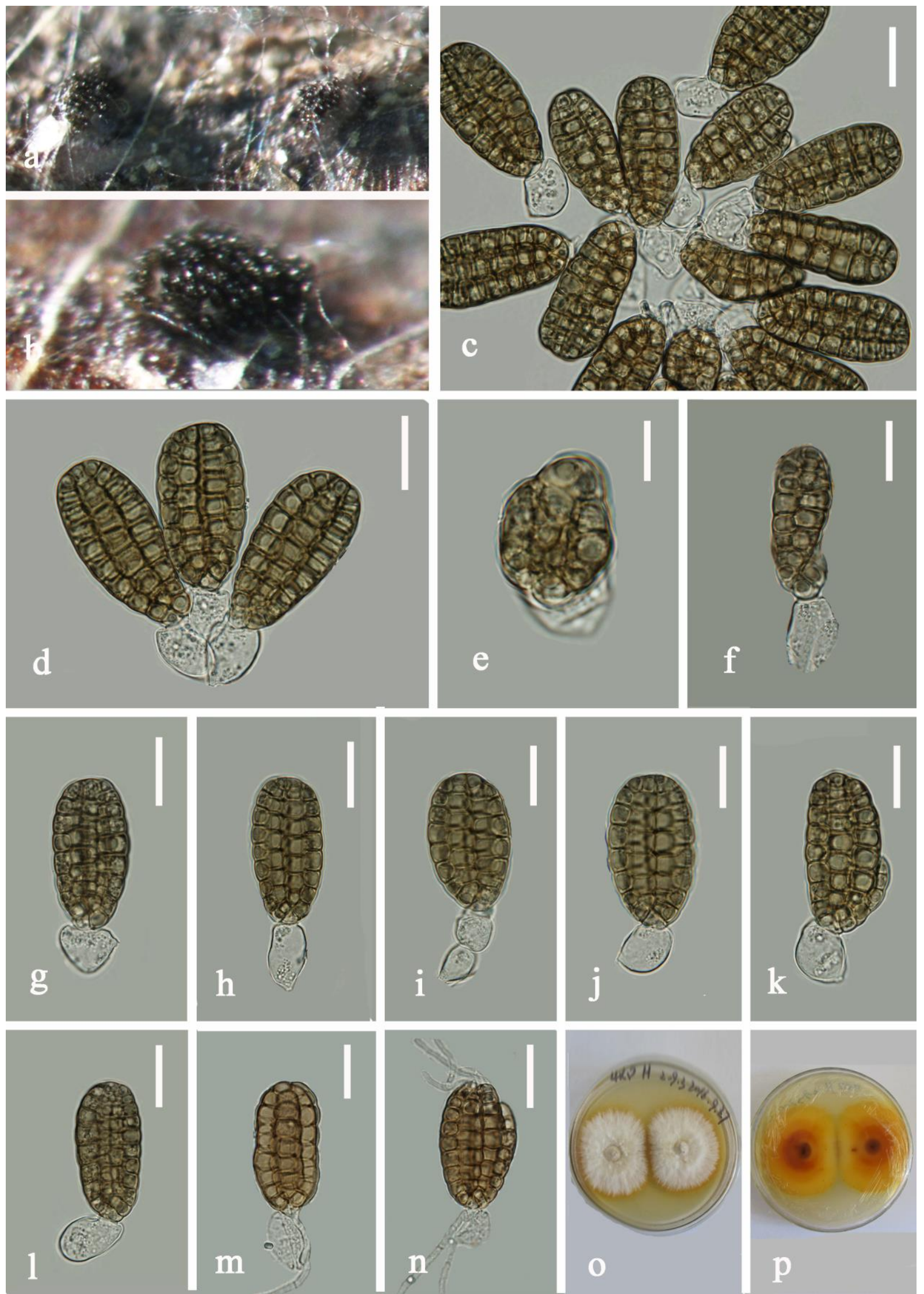

Figure 2 - Aquadictyospora lignicola. (MFLU 17-1422, holotype) a-b Colonies on wood. c-d Squash mount of conidia. e-i Conidia. $\mathrm{m}-\mathrm{n}$ Germinating conidium. o-p Colonies on PDA from surface and reverse. - Scale bars: $\mathrm{c}-\mathrm{n}=25 \mu \mathrm{m}$. 
holoblastic. Conidia appearing broadly rounded in upper half, composed of uniformly medium brown, compactly adpressed 4-6 apically curved rows of cells appearing muriform, cheiroid, 46-54 $\mu \mathrm{m}$ long $(\bar{x}=50 \mu \mathrm{m}, \mathrm{SD}=4, \mathrm{n}=40), 21-27 \mu \mathrm{m}$ wide, $(\bar{x}=24 \mu \mathrm{m}, \mathrm{SD}=3, \mathrm{n}=40)$; in lower half with a broadly ovate to subglobose, hyaline, smooth basal cell, 16-22 $\mu \mathrm{m}$ long $(\bar{x}=19 \mu \mathrm{m}, \mathrm{SD}=$ $3, \mathrm{n}=40), 12-15 \mu \mathrm{m}$ wide, $(\bar{x}=13.5 \mu \mathrm{m}, \mathrm{SD}=1.5, \mathrm{n}=40)$, not complanate, secession schizolytic. Conidial appendages absent.
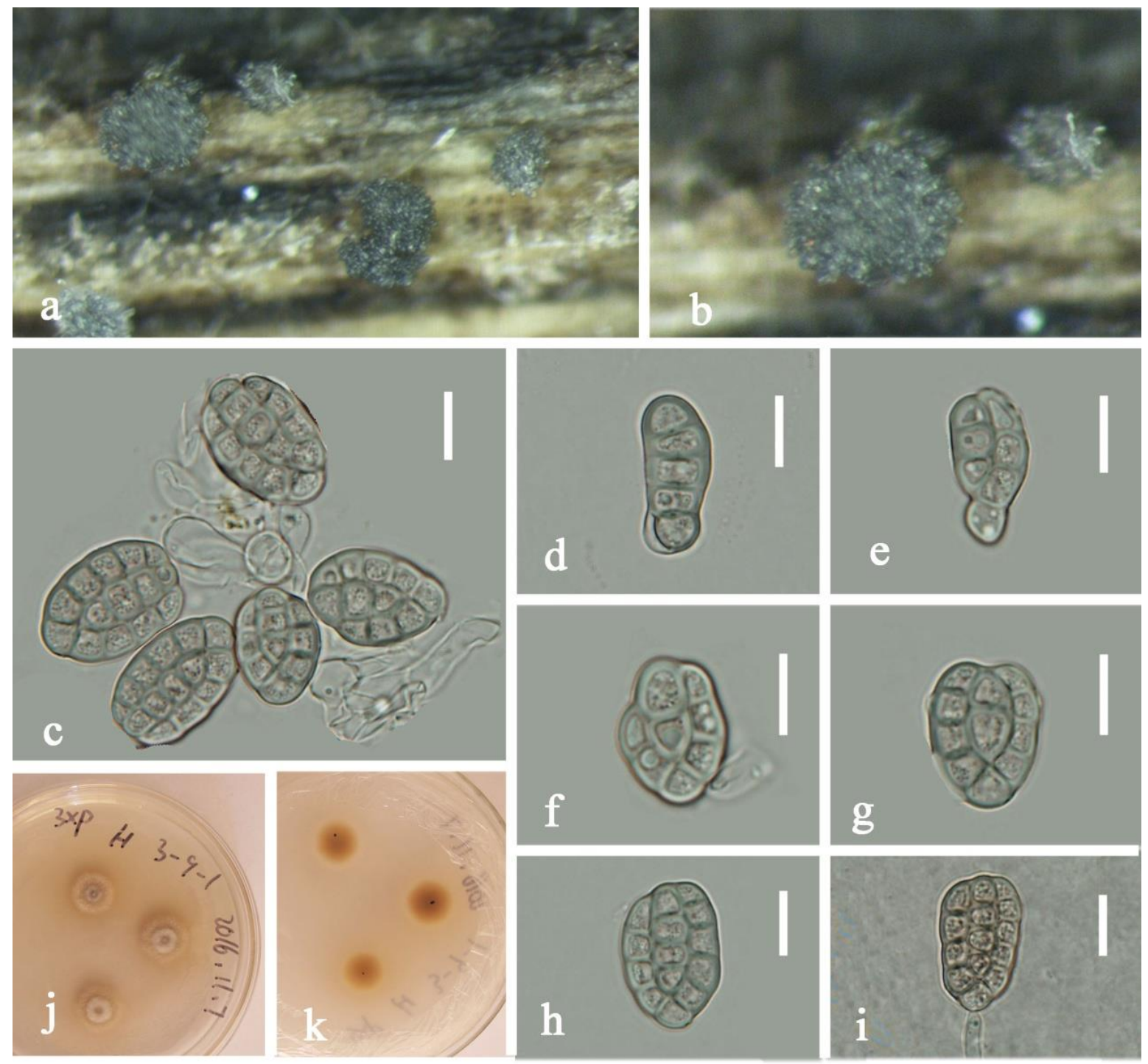

Figure 3 - Pseudodictyosporium wauense a-b Colonies on wood. c Conidiogenous cells. d-h Conidia. i Germinating conidium. $\mathrm{j}-\mathrm{k}$ Colonies on PDA from surface and reverse. - Scale bars: $\mathrm{c}-\mathrm{i}$ $=10 \mu \mathrm{m}$.

Pseudodictyosporium wauense Matsush. Bull. natn. Sci. Mus., Tokyo 14(3): 473 (1971)

Facesoffungi number: FoF03769, Fig. 3

Saprobic on submerged decayed wood in aquatic habitats. Sexual morph: Undetermined. Asexual morph: Hyphomycetous. Conidiomata on natural substratum sporodochia, superficial, punctiform to effuse, scattered, sometimes coalescing, pale brown to dark brown, with or without a mucilage covering, rarely inconspicuous. Mycelium immersed, composed of septate, branched, subhyaline to pale brown, smooth-walled hyphae. Conidiophores micronematous, aseptate, simple, hyaline to pale brown, smooth. Conidiogenous cells integrated, holoblastic, terminal, determinate, doliiform to cylindrical. Conidia 19.5-22.5 $\mu \mathrm{m}$ long $(\bar{x}=21 \mu \mathrm{m}, \mathrm{SD}=1.5, \mathrm{n}=50), 12.5-15.5 \mu \mathrm{m}$ wide, $(\bar{x}=$ $14 \mu \mathrm{m}, \mathrm{SD}=1.5, \mathrm{n}=50$ ), acrogenous, solitary, dry, cheiroid, very pale brown, smooth-walled, 
euseptate or distoseptate, consisting of a truncate basal cell on which three rows of cells arise parallelly and compactly with all 3 rows in different planes, with or without appendages.

Material examined - CHINA, Yunnan Province, Dali, saprobic on decaying wood submerged in a stream in Cangshan Mountain, June 2016, S.M. Tang, 3XP H 3-9-1, (DLU 0801), living culture DLUCC 0801.

Notes - Pseudodictyosporium wauense, the type species of Pseudodictyosporium, was introduced by Matsushima et al. (1971). In this study, an isolate was obtained from submerged decaying wood collected in Yunnan Province, China. Its morphological characters identify the taxon as Pseudodictyosporium wauense. Based on the phylogenetic study (Fig. 1), our strain clusters with two other isolates of P. wauense (NBRC 3007, KRP88-6) with good branch support (90\% ML). Therefore, the identification of this isolate is confirmed based on both morphology and phylogeny. It is a new record for China.

\section{Acknowledgements}

HongYan Su would like to thank the National Natural Science Foundation of China (NSFC 31460015, 31660008) and "Collaborative Innovation Center for Biodiversity and Conservation in the Three Parallel Rivers Region of China" for financial and laboratory support. ZongLong Luo thank Dr. Shaun Pennycook from Landcare Research, Auckland, New Zealand, for advising on the taxon name and thank RuXiao Wang, QiShan Zhou, ZhengPeng Li, QingXiong Ruan and HongWei Shen for their help on phylogeny and morphology work. JianKui Liu would like to thank the National Natural Science Foundation of China (NSFC 31600032) and Science and Technology Foundation of Guizhou Province (LH [2015]7061).

\section{References}

Bucher VVC, Hyde KD, Pointing SB, Reddy CA. 2004 - Production of wood decay enzymes, mass loss and lignin solubilization in wood by diverse freshwater fungi. Microbial Ecology 48, 331-337.

Boonmee S, D'souza MJ, Luo ZL, Pinruan U et al. 2016 - Dictyosporiaceae fam. nov. Fungal Diversity 80, 457-482.

Cai L, Tsui C, Zhang K, Hyde KD. 2002 - Aquatic fungi from Lake Fuxian, Yunnan, China. Fungal Diversity 9, 57-70.

Cai L, Zhang KQ, Hyde KD. 2005 - Ascoyunnania aquatica gen. et sp. nov., a freshwater fungus collected from China and its microcylic conidiation. Fungal Diversity 18, 1-8.

Cai L, Hyde KD. 2007 - Ascorhombispora aquatica gen. et sp nov from a freshwater habitat in China, and its phylogenetic placement based on molecular data. Cryptogamie, Mycologie 28, 291-300.

Carbone I, Kohn LM 1999 - A method for designing primer sets for speciation studies in filamentous ascomycetes. Mycologia, 553-556

Chomnunti P, Hongsanan S, Aguirre-Hudson B, Tian Q et al. 2014 - The sooty moulds. Fungal Diversity 66, 1-36.

Goh TK, Hyde KD. 1996 - Biodiversity of freshwater fungi. Journal of Industrial Microbiology \& Biotechnology 17: 328-345.

Goh TK, Hyde KD. 1999 - Fungi on submerged wood and bamboo in the Plover Cove Reservoir, Hong Kong. Fungal Diversity 3, 57-85.

Goh TK, Tsui KM, Hyde KD. 1998 - Elegantimyces sporidesmiopsis gen. et sp. nov. on submerged wood from Hong Kong. Mycological Research 102, 239-242.

Goh TK, Hyde KD, Ho WH, Yanna. 1999 - A revision of the genus Dictyosporium, with descriptions of three new species. Fungal Diversity 2, 65-100.

Hall TA 1999 - BioEdit: a user-friendly biological sequence alignmenteditor and analysis program for Windows 95/98/NT. Nucleic Nucleic Acids Symposium Series 41, 95-98. 
He SC. 1988. A new record genus and species of aquatic cup fungi from China. Acta Mycologica Sinica 7, 120-121.

Ho WH, Ranghoo VM, Hyde KD, Hodgkiss IJ. 1999 - Ascal ultrastructural study in Annulatascus hongkongensis sp nov., a freshwater ascomycete. Mycologia 91, 885-892.

Hu DM, Chen H, Cai L, Bahkali AH et al. 2012 - Aquapeziza: a new genus from freshwater, and its morphological and phylogenetic relationships to Pezizaceae. Mycologia 104, 540-546.

Hu DM, Liu F, Cai L. 2013 - Biodiversity of aquatic fungi in China. Mycology 4, 125-168.

Hyde KD, Goh TK. 1998 - Tropical Australian Freshwater Fungi XIII. A new species of Anthostomella and its sporodochial Geniculosporium anamorph. Nova Hedwigia 67, 225233.

Hyde KD, Jones EBG, Liu JK, Ariyawansa HA et al. 2013 - Families of Dothideomycetes. Fungal Diversity 63, 1-313.

Hyde KD, Fryar S, Tian Q, Bahkali AH et al. 2016 - Lignicolous freshwater fungi along a northsouth latitudinal gradient in the Asian/Australian region; can we predict the affects of global warming on biodiversity and function? Fungal Ecology 19, 190-200.

Index Fungorum 2017 - http : // www. Indexfungorum.org/names/IndexFungorum Register. htm (August 2017).

Inderbitzin P. 2000 - Ceratostomella hyalocoronata, a new pyrenomycete from a stream in southern China. Mycoscience 41, 167-169.

Jayasiri SC, Hyde KD, Ariyawansa HA, Bhat DJ et al. 2015 - The Faces of Fungi database: fungal names linked with morphology, phylogeny and human impacts. Fungal Diversity 74, 3-18.

Jeewon R, Cai L, Liew ECY, Zhang KQ et al. 2003 - Dyrithiopsis lakefuxianensis gen. et sp. nov. from Fuxian Lake, Yunnan, China, and notes on the taxonomic confusion surrounding Dyrithium. Mycologia 95, 911-920.

Katoh K, Standley DM 2013 - MAFFT multiple sequence alignment software version 7: improvements in performance and usability. Molecular Biology \& Evolution 30, 772-780.

Liu JK, Hyde KD, Jones EBG, Ariyawansa HA et al. 2015 - Fungal diversity notes 1-110: taxonomic and phylogenetic contributions to fungal species. Fungal Diversity 72, 1-197.

Liu JK, Hyde KD, Jeewon R, Phillips AJL et al. 2017 - Ranking higher taxa using divergence times: a case study in Dothideomycetes. Fungal Diversity 84: 75-99.

Liu XY, Udayanga D, Luo ZL, Chen LJ et al. 2015 - Backbone tree for Chaetothyriales with four new species of Minimelanolocus from aquatic habitats. Fungal Biology 119, 1046-1062.

Luo J, Yin JF, Cai L, Zhang KQ et al. 2004 - Freshwater fungi in Lake Dianchi, a heavily polluted lake in Yunnan, China. Fungal Diversity 16, 93-112.

Luo ZL, Bao DF, Bhat DJ, Yang J et al. 2016 - Sporoschisma from submerged wood in Yunnan, China. Mycological Progress 15, 1145-1155.

Luo ZL, Bhat DJ, Jeewon R, Boonmee S et al. 2017 - Molecular phylogeny and morphological characterization of asexual fungi (Tubeufiaceae) from freshwater habitats in Yunnan, China. Cryptogamie Mycologie 38(1), 27-53.

Maharachchikumbura SSN, Hyde KD, Jones EBG, McKenzie EHC et al. 2015 - Towards a natural classification and backbone tree for Sordariomycetes. Fungal Diversity 72, 199-301.

Maharachchikumbura SSN, Hyde KD, Jones EBG, McKenzie EHC et al. 2016 Families of Sordariomycetes. Fungal Diversity 79, 1-317.

Matsushima T. 1971 - Some interesting fungi imperfecti. In: Kobayasi Y (ed) Mycological reports from New Guinea and the Solomon Islands (1-11), Bull Net Sci. Mus Tokyo 14, 460-480.

Nylander JAA. 2004 - MrModeltest 2.0 Program distributed by the author. Evolutionary Biology Centre, Uppsala University

Page RD. 1996 - TREEVIEW: an application to display phylogenetic trees on personal computers. Computer Applications in the Biosciences 12, 357-358.

Rannala B, Yang Z. 1996 - Probability distribution of molecular evolutionary trees: a new method of phylogenetic inference. Journal of Molecular Evolution 43, 304-311. 
Ranghoo VM, Hyde KD. 1998 - Ascomycetes from freshwater habitats: Ascolacicola aquatica gen et sp nov and a new species of Ascotaiwania from wood submerged in a reservoir in Hong Kong. Mycologia 90, 1055-1062.

Reddy KA, Rao V. 1984 - Bahugada -A new hyphomycetes. Current Science, 53, 542-544.

Ronquist F, Teslenko M, Van der Mark P, Ayres DL et al. 2012 - MrBAYES 3.2: efficient Bayesian phylogenetic inference and model choice across a large model space. Systematic Biology 61, 539-542.

Silvestro D, Michalak I. 2011 - RAxML-GUI: a graphical front-end for RAxML. Organisms Diversity \& Evolution 12, 335-337.

Su HY, Udayanga D, Luo ZL, Manamgoda DS et al. 2015 - Hyphomycetes from aquatic habitats in Southern China: Species of Curvularia (Pleosporaceae) and Phragmocephala (Melanommataceae). Phytotaxa 226, 201-216.

Su HY, Hyde KD, Maharachchikumbura SSN, Ariyawansa HA, Luo ZL et al. 2016a - The families Distoseptisporaceae fam. nov., Kirschsteiniotheliaceae, Sporidesmiaceae and Torulaceae, with new species from freshwater in Yunnan Province, China. Fungal Diversity 80, 375-409.

Su HY, Luo ZL, Liu XY, Su XJ et al. 2016b - Lentithecium cangshanense sp. nov. (Lentitheciaceae) from freshwater habitats in Yunnan Province, China. Phytotaxa 267 (1), 061-069.

Swofford DL. 2002 - PAUP: phylogenetic analysis using parsimony. Version 4.0b10. Illinois Natural History Survey, Champion, III.

Tanaka K, Hirayama K, Yonezawa H, Hatakeyama S et al. 2009 - Molecular taxonomy of bambusicolous fungi: Tetraplosphaeriaceae, a new pleosporalean family with Tetraploa-like anamorphs. Studies in Mycology 64(1), 175-209.

Tanaka K, Hirayama K, Yonezawa H, Sato G et al. 2015 - Revision of the Massarineae (Pleosporales, Dothideomycetes). Studies in Mycology 82, 75-136.

Taylor JE, Hyde KD. 2003 - Microfungi on Tropical and Temperate Palms. In: Fungal Diversity Research Series 12, 1-459.

Tsui KM, Hyde KD, Hodgkiss IJ. 1997 - A news species of Aniptodera (Ascomycetes) from Hong Kong and the Philippines. Sydowia 49, 187-192.

Tsui CKM, Hyde KD, Hodgkiss IJ 2000 - Biodiversity of fungi on submerged wood in Hong Kong streams. Aquatic Microbial Ecology 21, 289-298.

Tsui CKM, Goh TK, Hyde KD, Hodgkiss IJ. 2001a - New records or species of Dictyochaeta, Endophragmiella and Ramichloridium from submerged wood in Hong Kong freshwater streams. Cryptogamie Mycologie 22, 139-145.

Tsui CKM, Goh TK, Hyde KD, Hodgkiss IJ. 2001b. - New species or records of Cacumisporium, Helicosporium, Monotosporella and Bahusutrabeeja on submerged wood in Hong Kong streams. Mycologia 93, 389-397.

Tsui CKM, Hodgkiss IJ, Hyde KD. 2003 - Three new species of Aquaticola (Ascomycetes) from tropical freshwater habitats. Nova Hedwigia 77, 161-168.

Vilgalys R, Hester M. 1990 - Rapid genetic identification and mapping of enzymatically amplified ribosomal DNA from several Cryptococcus species. Journal of Bacteriology 172, 4238-4246.

Wang RX, Luo ZL, Hyde KD, Bhat DJ et al. 2016 - New species and records of Dictyocheirospora from submerged wood in north-western Yunnan, China. Mycosphere 7, 1357-1367.

White TJ, Bruns T, Lee S, Taylor J. 1990 - Amplification and direct sequencing of fungal ribosomal RNA genes for phylogenetics. In: Innis, Gelfand M, Shinsky D, White T (eds) PCR protocols: a guide to methods and applications. Academic, New York, pp 315-322.

Wijayawardene NN, Crous PW, Kirk PM, Hawksworth DL et al. 2014 - Naming and outline of Dothideomycetes-2014 including proposals for the protection or suppression of generic names. Fungal Diversity 69, 1-55.

Wong KMK, Goh TK, Hodgkiss IJ, Hyde KD et al. 1998 - Role of fungi in freshwater ecosystems. Biodiversity and Conservation 7, 1187-1206. 
Wongsawas M, Wang HK, Hyde KD, Lin FC. 2009a - Two new hyphomycetes from submerged wood collected in China. Sydowia 61, 345-351.

Wongsawas M, Wang HK, Hyde KD, Lin FC. 2009b - Dictyosporium zhejiangense sp. nov., a new freshwater anamorphic fungus from China. Cryptogamie, Mycologie 30, 355-362.

Yang YM, Tian K, Hao JM, Pei SJ, Yang YX. 2004 - Biodiversity and biodiversity conservation in Yunnan, China. Biodiversity and Conservation 13, 813-826.

Yuen TK, Hyde KD, Hodgkiss IJ. 1998 - Physiological growth parameters and enzyme production in tropical freshwater fungi. Material und Organismen 32, 2-6.

Zhang Y, Crous PW, Schoch CL, Hyde KD. 2012 - Pleosporales. Fungal Diversity 53, 1-221.

Zhu D, Luo ZL, Baht DJ, McKenzie EHC et al. 2016 - Helminthosporium velutinum and $H$. aquaticum sp. nov. from aquatic habitats in Yunnan Province, China. Phytotaxa 253, 179190. 